\title{
Facilitative Learning to Improve Student Learning Creativity
}

\author{
Hardika \\ Department of Non-Formal Education \\ State University of Malang, Indonesia \\ hardika.fip@um.ac.id
}

\author{
Eny Nur Aisyah \\ Department of Early Childhood Education \\ State University of Malang, Indonesia \\ eny.nur.fip@um.ac.id
}

\author{
Imam Gunawan \\ Departement of Administration Education \\ State University of Malang, Indonesia \\ imam.gunawan.fip@um.ac.id
}

\begin{abstract}
This study aims to describe learning problems related to efforts to increase creativity and independence of student learning. The learning innovation developed is a model of transformative learning based on the principle of learning transfer, which positions the lecturer as a learning facilitator and students as the subject of learning. The method used is research and development $(\mathrm{R} \& \mathrm{D})$. The results of this study conclude that transformative learning based on transfer of learning can create the flexibility of students to actualize and express in learning so as to produce creativity and independence of learning.
\end{abstract}

Keywords: transformative learning, transfer of learning, creativity learning

\section{INTRODUCTION}

The rapid development of information technology, forcing people to adapt and anticipate the profession and work faced. Educational interactions related to the transfer of knowledge and skills also experience changes, both in terms of academic content and delivery strategies. There is also a change in the field of learning and shifts in terms of processes, strategies and objectives. Learning is not only a transfer of knowledge, but also an activity that produces a transformation of mindset and action patterns [1]. Learning in cognitive psychology is not only a passive process of receiving information, but is an active thinking process to make meaningful throughout the learning experience. Learning is also not only the fulfillment of intellectual needs with coercion. Learning must be done with the willingness of students to be involved and actively involved in the learning interaction process [2,3]. Student involvement in learning is directed at forming trust in their potential and abilities. The learning process must be able to create student characters who are always ready to face and overcome challenges in life and create a comfortable learning atmosphere without causing pressure on students [4].

Likewise in learning at the university. Learning is not only to achieve graduation rates, but is able to create learning independence and creativity and usefulness in life. The intellectual capacity built into the learning system is directed towards enhancing students' ability to manage themselves and their environment. Students are encouraged to have the courage to improvise and build more dynamic learning interactions. This needs to be done, because the learning styles and strategies of each student are different, according to the individual and social characteristics of the environment [5]. Therefore, creativity and learning activities begin by creating a pleasant learning atmosphere, involving potential students, the surrounding environment, developing facilitation strategies that are appropriate to educational goals [6].

But student learning creativity is not considered important by some teachers. Some teachers still like students who have a high level of integrity than creativity or other intelligence [7]. Teachers with this understanding can be assumed that the learning patterns that have been going on so far will not be able to show creative learning processes and results with smart ideas. Students with high creativity will be able to better manage themselves and the environment to produce what is needed.

Creativity in learning in education is still not well implemented. The learning process has not resulted in changes in learning attitudes, behaviors, and insights in accordance with the philosophy of learning in education, namely creative learning with a high level of independence. Students have the ability and willingness to research learning material that is lacking, so that in dealing with learning is only considered as fulfilling obligations, without understanding and critical thinking. Munandar and Makiguchi stated that creativity can be built through a constructive learning system in an atmosphere of mutual respect for the behavior and achievements of each student. Efforts to create learning creativity must be done by exploring and developing students through learning activities related to their potential. Students' interests and talents will be detected and developed through learning models that have relevance to the creation of learning creativity $[6,8]$.

Makiguchi revealed that to build learning creativity, educational institutions must make a total reflection on the goals, basics of values, revitalization, and understand various educational methodologies and teaching materials. Student learning creativity in this context can be developed through the process of exploration and reconstruction of learning models, which are rooted in the character and potential of students. Therefore, the learning model must be built 
on the basis of: a reflection of the purpose and nature of the value of education; the right learning methodology; learning tools and materials in accordance with the learning mission; and able to arouse high interest and enthusiasm for learning [8].

Lecturers as facilitators have also not been seen in the learning interaction process. Lecturers tend to intervene about learning patterns for students, so students' learning creativity is less developed. Lecturers lack the will and ability to design and implement student-centered learning models. So that the facilitation model of learning that leads to the formation of student independence and creativity is still not much done by lecturers.

Students with a lot of maturity and life experience, have the responsibility and ability to learn to do learning activities independently and professionally [9]. Development of learning models that can improve the understanding and ability of lecturers in creating learning creativity has urgency in improving the quality of learning. The quality of good learning is prioritizing transformative principles in every learning interaction, so as to be able to contribute in changing students' lives.

\section{METHODS}

This research was carried out using a qualitative descriptive approach [10]. The goal achieved in this study was to produce new products about facilitative learning models that can enhance student learning creativity. The study was conducted on two groups of subjects as experimental and comparison groups, for the purpose of testing the effectiveness of the model.

Experimental group, learning models are provided with facilitative learning design. The comparison group, given a structured learning model centered on the lecturer. Researchers in the use of this design, referring to the Sprinthall theory, by doing posttest, either to the experimental group or comparison group without pretest, because the initial data on the creativity of learning in the experimental group was known at the time of the initial study [16].

\section{RESULTS}

The learning model that has been applied to the lecture process has not been able to create creativity. Therefore, students depend on the presence of lecturers. This affects the dynamics and intensity of learning, because the presence of lecturers is very dominant in learning. Such conditions are very contrary to the philosophy of learning which prioritizes independent learning with the facilitation model of lecturers. The findings of this study conclude that the facilitative learning model empirically can improve the creativity of learning, both at the stage of planning, implementing, and evaluating learning.

Some of the findings that are the main focus of facilitative learning, are: (1) adult learning organization system; (2) the role and position of the lecturer as a learning partner; (3) reflection on community education goals; (4) learning as a process to make students learn independently; (5) social communication techniques; (6) availability of learning resources that are relevant to students' needs; (7) identify the needs and learning resources of students; and student characteristics. Therefore, to maximize the results of facilitative learning, lecturers need to be trained in improving and updating understanding of learning facilitation.

Learning creativity is a learning product that can be achieved through learning design oriented to the processes and problems faced by students (problem posing model). This model is carried out by encouraging students' active participation, making the student experience as a material for discussion in learning, the learning atmosphere is designed by actively involving students and evaluations carried out jointly (lecturers and students) through reflective tests.

The substance of this facilitative learning model is: (1) the lecturer as a facilitator in learning; (2) students as the main actors in learning; (3) utilizing the environment and experience of students as learning resources; (4) using persuasive words; (5) using ice breaking in reducing learning tension; (6) creativity as the main learning output; and (7) using reflective evaluation in the framework of training with a critical amount.

Facilitative learning models have flexibility and are feasible to be applied in non-formal education. The application of this model is influenced by the ability and willingness of the lecturer to describe himself as a facilitator, namely: (1) the ability to use persuasive words; (2) the ability to create a fresh learning atmosphere (ice breaking); and (3) placing students as learning subjects and lecturers only design learning interactions.

The role of the lecturer in this case is: (1) as a catalyst, (2) connecting resources, (3) helping the process; and (4) help identify alternative solutions to student problems. This role is applied flexibly according to the situation and needs of students. The role of the lecturer as a learning facilitator is to pay attention to the philosophy of "learning how to learn", by learning by facilitating principles, learning together, learning through dialogue, learning with independence, learning with the social environment, and learning to be yourself.

The product of this research is about learning creativity, which is in the form of student performance in the learning process, and then student involvement is built since lesson preparation. Student involvement is carried out by encouraging students: (1) to undertake a learning contract; (2) discuss the learning model that will be applied; (3) revive learning motivation with persuasive and ice breaking words, consistent, and constructive; (4) learning to reconstruct the nature of learning; and (5) evaluation of learning through selfevaluation, critical thinking, self-determination, and self-awareness.

\section{DISCUSSION}

Referring to the research findings, it is necessary to optimize the role of the lecturer as a learning facilitator, taking into account the character, situation and condition of students, and the potential of 
the learning environment and student learning experience. Characteristics of the role of lecturers in learning are: (1) lecturers always respond to students' feelings; (2) dialogue and discussion with students; (3) formulating learning models in accordance with the characteristics and learning environment of students; (4) familiar and open with students; (5) being empathic, respectful and sensitive to the will and students feeling; and (6) utilizing students' ideas and experiences to formulate learning models.

When referring to the results of the study, there are three things that need to be considered in facilitative learning, namely: (1) increasing the capacity and ability of lecturers in understanding the character of students and learning objectives; (2) student achievement and graduation awards are viewed comprehensively from the performance aspen at the time of learning implementation; (3) quality and feasibility of student portfolios during learning; and (4) conducting a variety of learning models and various learning facilities.

The four attributes empirically have a contribution in changing students' attitudes and behavior to be more active, interesting, and creative in learning [11]. Changes in learning attitudes and behaviors that are more interesting and transformative can increase students' learning motivation [11]. Schwarz states facilitative learning has the power to move group dynamics to achieve goals [15]. The facilitator has an obligation to help increase the effectiveness of activities with high commitment from all group members. Group member commitment is one of the keys or core of facilitative learning. The main task of the facilitator is to help groups improve their effectiveness by improving their processes and structures. The core value of facilitation is a more effective group when the group is internally committed to its choices [15].

Group agreements that have been formulated together, such as the contents of the learning contract, become joint commitments through class enhancement and empowerment. Class is a relevant learning forum in facilitative school-based learning education. Group process does not mean leaving the intensity and capacity of each student, but the learning process is carried out on the basis that students learn from each other and respect each other. Hackman stated that there were three factors that contributed positively to increasing group effectiveness, namely: group process, group structure, and group context [15]. Groups must be able to move and work well, have the right management structure and structure, and have relevance or attention to the context and objectives of the group concerned [11]. The problem-based model of facilitation learning is shown in Figure 1.

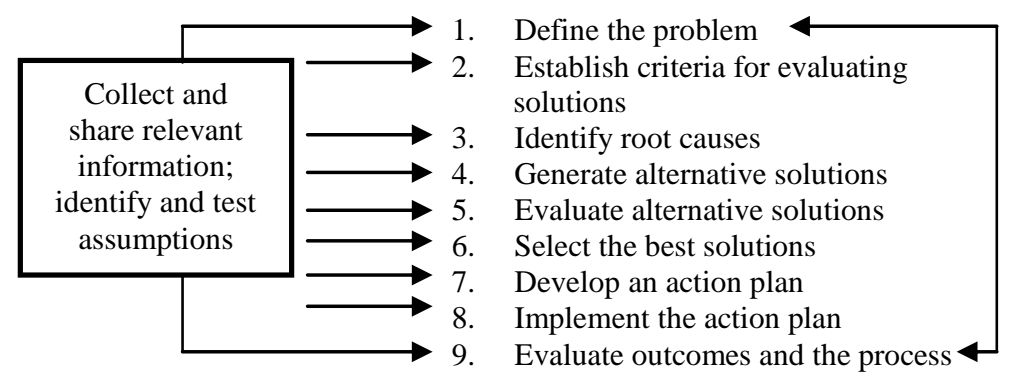

Figure 1

The Problem-Based Model of Facilitation Learning (Schwarz, 2002)

Learning activities are carried out with the aim that students can achieve optimal learning outcomes, by moving all learning systems, through professional management and school organizations. The group process, structure, and context must be based on improving the capacity and professionalism of lecturers, class climate, availability of resources, and the professionalism of the administration team. The development of creativity through facilitative learning has a significant influence on changes in student learning attitudes. Discussions about creative learning attitudes will involve factors that influence the occurrence of change and the formation of one's attitude towards objects. The important thing is always related to relevance, attractiveness, and object attitude (in this case a facilitative learning model).

Formation and change in student attitudes do not occur on their own, but occur from the interaction with others, related to the learning model applied [12]. Factors that influence changes in student attitudes can be derived from external or internal students. However, however great the influence from outside, if the internal factors of students want to accept it, it will not result in a new attitude change. Therefore, the facilitative learning model as an object of attitudes will certainly be responded to by students, if it has the attraction, relevance, external and internal encouragement of the students.

Creativity is not purely innate talent, but is the result of an educational process that involves optimal environmental potential. Educator power in changing the potential of the environment as a learning and engineering character of students as the subject of learning. Creativity will emerge after going through a process of social engineering that involves all elements of the environment. Social engineering in question is the creation of a creativogoneic cultural atmosphere. Creativogoneic according to Arieti is a culture that supports, fosters, and enables the development of one's creativity in the life system [7]. 
Compared to other attributes, creativity is still relatively new as a field of academic activity that has a system and becomes empirical research. Creativity research was expressed empirically in the context of learning after the Second World War through a historic speech in 1950 by Guilford as President of the American Psychological Association (APA). Guilford emphasized the neglect of the importance of the study of creativity and a reminder of the need for creativity in society, through learning and education systems. The launch of Sputnik 1957 was also seen as a threat to America to maintain its technological superiority. This encourages Americans to foster education based on student creativity. Both events are considered by educators as the forerunner of creativity as an empirical study in various learning systems [7].

Creativity has become the focus of important studies in the education system and spread to various human activities, both in the learning system and the world of work. Creativity today is an integral part that cannot be separated from one's intelligence system, other than intellectual, social, emotional, and spiritual intelligence. Creativity can be traced from the abilities of convergent thinking and different thoughts. Convergent thinking with logical reasoning is the process that underlies the measurement of traditional intelligence. While different thoughts are thought patterns that generate ideas and are the clearest indicators of creativity.

A critical problem in the development of creative thinking is the question of criteria. It is not easy to formulate the right criteria in finding and developing creativity. Makiguchi reminded that it is impossible to find criteria for creativity that are not mixed with other human characteristics and behaviors, especially intelligence, because creativity is a multidimensional construction [8]. Most teachers still side with children who have high intelligence compared to children who have a good foundation of creativity. Empirical facts show that creativity has advantages in many ways, including its ability to solve problems and problems that are solved by those who have high integrity [7]. Teachers to create an atmosphere that fosters creativity, must be able to position itself as a good companion, act as a catalyst, process aides, connecting resources, and assisting solutions. The principle of lifelong learning becomes the foundation in the learning process and is able to provide educational values, especially in strengthening human character as a true learner [14]. In this way, the lecturer not only applies knowledge transfer to students, but emphasizes the transfer of the process.

\section{CONCLUSION}

Based on the analysis of research data, it is known that the model of transformative learning in learning programs can improve students' creativity in learning, both at the planning, implementation and evaluation stages of learning. The results of the analysis prove that students' learning creativity using a facilitative learning model is different than learning creativity that does not use facilitative learning models. The learning process with students, who have learning creativity, is more interesting, dynamic, challenging, and fun.

The substance of the transformative learning model is: (1) the lecturer as a facilitator in learning; (2) students as the main actors in learning; (3) utilizing the environment and experience of students as learning resources; (4) using persuasive words; (5) using ice breaking in reducing learning tension; (6) creativity as the main learning output; and (7) using reflective evaluation in the framework of training with a critical amount.

\section{REFERENCES}

[1] Novak, J. D., \& Gowin, B. D. 2004. Learning How to Learn. Cambridge University Press.

[2] Knowles, M. S. 1988. The Adult Learner A Neglected Species. Houston: Gulf Publishing Company.

[3] Harefa, A. 2005. Menjadi Manusia Pembelajar (On Becoming A Learner): Pemberdayaan Diri, Transformasi Organisasi dan Masyarakat Lewat Proses Pembelajaran. Jakarta: PT Kompas Media Nusantara.

[4] Gilbert, I. 2003. Essential Motivation in Classroom. New York. Roudledge Falmer.

[5] Pask, G. 1977. Styles and Strategies of Learning. British Joernal of Educational Psychology, 46.

[6] Macaulay, C. 2000. Transfer of Learning in Professuional and Vocational Education. Edinburgh: University of Edinburgh.

[7] Munandar, S. C. U. 1999. Creativity and Education: A Studi of The Relationshis between Measures of Creative Thinking and A Number of Educational Variables in Indonesian Primary and Junior Secondary Schools. Jakarta: Ditjen Dikti Depdikbud

[8] Makiguchi, T. 1989. Education for Creative Living. Iowa University Press/Ames.

[9] Kamil, M. 2007. Teori Andragogi dalam Ilmu dan Aplikasi Pendidikan. Bandung: Pedagogiana Press.

[10] Borg, W. R., \& Gall, M. D. 2003. Educational Research: An Introduction. New York: Longman.

[11] Aldeman, M. K. 2004. Motivation for Achievement, Possibilities for Teaching and Learning. London: Lowrence Erlbaum Associatis Publishers.

[12] King, K. P. 2005. Bringing Transformative Learning to Life. Malabar, Florida: Krieger Publising Company.

[13] Thomas, G. 2007. Education and Theory Strangers in Paradigms. New York. Open University Press.

[14] Aspin, D. N., \& Chapman, Y. D. 2007. Values Education and Lifelong Learning: Principles, Policies, Programmes. Netherland: Springer.

[15] Schwarz, R. 2002. The Skilled Facilitator: A Comprehenvive Resource for Consultants, Facilitators, Managers, and Coaches. San Francisco. Jossey Bass A Willey Company.

[16] Sprinthall, R. C., Schumutte, G. T., Sirois, L. 1991. Understanding Educational Research. New Jersey: Prentice Hall Inc. 